\title{
Phytoremediation: green technology for the clean up of toxic metals in the environment
}

\author{
Priscila Lupino Gratão ${ }^{1}$, Majeti Narasimha Vara Prasad ${ }^{2}$, Patrícia Felippe Cardoso ${ }^{3}$, Peter John Lea ${ }^{4}$ and \\ Ricardo Antunes Azevedo ${ }^{1, *}$
}

\begin{abstract}
${ }^{1}$ Departamento de Genética, Escola Superior de Agricultura Luiz de Queiroz, Universidade de São Paulo, CEP 13418-900, Piracicaba, SP, Brasil; ' 2 Department of Plant Sciences, School of Life Sciences, University of Hyderabad, Hyderabad 500 046 , India; ${ }^{3}$ Departamento de Genética e Evolução, Instituto de Biologia, Universidade Estadual de Campinas, CEP 13083-970, Campinas, SP, Brasil; ${ }^{4}$ Department of Biological Sciences, University of Lancaster, Lancaster LA1 4YQ, United Kingdom. *Corresponding author: raazeved@esalq.usp.br
\end{abstract}

\begin{abstract}
The contamination of the environment by toxic metals poses a threat for "Man and biosphere", reducing agricultural productivity and damaging the health of the ecosystem. In developed nations, this problem is being addressed and solved to some extent by using "green technology" involving metal tolerant plants, to clean up the polluted soils. The use of naturally occurring metal tolerant plants and the application of genetic manipulation, should hasten the process of transferring this technology from laboratory to field. Therefore, it is essential to investigate and understand how plants are able to tolerate toxic metals and to identify which metabolic pathways and genes are involved in such a process. Recent advances in knowledge derived from the "omics", have considerable potential in developing this green technology. However, strategies to produce genetically altered plants to remove, destroy or sequester toxic metals from the environment and the long-term implications, must be investigated carefully.
\end{abstract}

Key words: hyperaccumulator plants, phytoremediation, toxic metals.

Fitorremediação: tecnologia verde na limpeza de metais tóxicos do ambiente: A contaminação do ambiente por metais tóxicos torna-se uma ameaça tanto para o homem quanto para a biosfera, impedindo o desenvolvimento da agricultura e prejudicando os ecossistemas. Em nações desenvolvidas, esse problema está sendo direcionado e resolvido, consideravelmente, com o uso de plantas tolerantes especializadas na limpeza de substratos contaminados e poluídos com metais. O uso de plantas que naturalmente acumulam metais e a aplicação da engenharia genética acelerariam o processo de transferência de toda essa tecnologia do laboratório ao campo. É essencial, portanto, investigar e entender como essas plantas funcionam e quais os caminhos metabólicos e genes envolvidos no processo. A combinação das tecnologias das "ômicas" tem um prodigioso potencial no desenvolvimento dessa tecnologia verde. Entretanto, estratégias para produzir plantas geneticamente alteradas para remoção, destruição ou seqüestro de substâncias tóxicas do ambiente e suas implicações devem ser cuidadosamente investigadas.

Palavras-chave: plantas hiperacumuladoras, fitorremediação, metais tóxicos.

\section{INTRODUCTION}

The contamination of the environment with toxic metals has become a worldwide problem, affecting crop yields, soil biomass and fertility, contributing to bioaccumulation in the food chain. In the last few decades, research groups have recognised that certain chemical pollutants such as toxic metals, may remain in the environment for a long period and can eventually accumulate to levels that could harm humans. Moreover, the numerous classes and types of these chemicals, complicate the removal of many toxic metals from the environment. As an alternative, an ecological technological approach has been developed involving the use of plants to clean up or remediate soils contaminated with toxic metals. Certain plants, termed hyperaccumulators, have been shown to 
be resistant to heavy metals and are capable of accumulating and transporting these soil pollutants to high concentrations. Thus, biological and engineering strategies designed to improve the use of phytoremediation to reduce the amount of heavy metals in contaminated soils, has begun to emerge.

\section{Toxic metals}

The focus of researchers on the phytoremediation of toxic metals in the environment has been considered an area of major scientific and technological progress and is a subject of contemporary relevance (Table 1). The widespread accumulation of heavy metals in soils is becoming a serious problem, as a consequence of industrial activity worldwide. Mining wastes, fertilisers, paper mills and toxic elements from atmospheric emissions, have all contributed to the continuous deposition and resulting accumulation of toxic metals in the environment. The concentrations of toxic metals in polluted soils are often hundreds of times greater than that required to exert a toxic effect on the majority of higher plants. Toxic metals can affect the biosphere for long periods of time and can be leached through the soil layers leading to the contamination of the water table. Consequently, the use of plants contaminated with high levels of heavy metals for food, might pose a serious risk to human and animal health (Wang et al., 2003).

Table 1. Social and economic dimensions of toxic trace elements, metalloids and radionuclides and areas of scientific investigation (Prasad 2004a).

\begin{tabular}{|c|c|}
\hline Area & Scope for detailed investigation \\
\hline $\begin{array}{l}\text { Ecotoxicology and } \\
\text { ecophysiology }\end{array}$ & $\begin{array}{l}\text { Nutrient availability efficiency } \\
\text { and deficiency for optimization } \\
\text { of crop yield }\end{array}$ \\
\hline $\begin{array}{l}\text { Environmental chemistry } \\
\text { waste management } \\
\text { and mine reclamation }\end{array}$ & $\begin{array}{l}\text { Bioremediation and restoration } \\
\text { of metal contaminated and } \\
\text { polluted ecosystems }\end{array}$ \\
\hline $\begin{array}{l}\text { Agricultural and } \\
\text { nutritional sciences } \\
\text { food industry }\end{array}$ & $\begin{array}{l}\text { Plant and soil serve as vital links } \\
\text { for supplementing nutrients } \\
\text { on sustainable basis }\end{array}$ \\
\hline $\begin{array}{l}\text { Clinical } \\
\text { biochemistry }\end{array}$ & $\begin{array}{l}\text { Usage of radiolabelled antibodies } \\
\text { and their disposal }\end{array}$ \\
\hline $\begin{array}{l}\text { Medicine and } \\
\text { pharmacology }\end{array}$ & $\begin{array}{l}\text { Use of plants as a source of } \\
\text { certain disorders nutrients for }\end{array}$ \\
\hline $\begin{array}{l}\text { The atomic } \\
\text { energy sector }\end{array}$ & $\begin{array}{l}\text { The nuclear weapon testing (release } \\
\text { of mainly }{ }^{14} \mathrm{C},{ }^{137} \mathrm{Cs},{ }^{90} \mathrm{Sr} \text { and }{ }^{95} \mathrm{Zr} \text { ) } \\
\text { production (release of mainly } \\
{ }^{137} \mathrm{Cs},{ }^{106} \mathrm{Ru},{ }^{95} \mathrm{Zr} \text { ) and nuclear } \\
\text { power production }\end{array}$ \\
\hline
\end{tabular}

\section{Phytoremediation: present outcomes}

Phytoremediation is the process that introduces plants into an environment and allows them to assimilate the contaminants into their roots and leaves. Such a process has been used to clean up heavy metals, pesticides and xenobiotics (Suresh and Ravishankar, 2004), organic compounds (Newman and Reynolds, 2004), toxic aromatic pollutants (Singh and Jain, 2003) and acid mine drainage (Archer and Caldwell, 2004). Interestingly, phytoremediation was recognized and documented by humans more than 300 years ago, however the scientific study and development of suitable plants was not conducted until the early 1980's (Lasat, 2000).

Phytoremediation is considered to be an environmentally friendly technology, that is a safe and also a cheap way to remove contaminants, in some cases doing the same job as a group of engineers for one tenth of the cost. However, such technology cannot necessarily be effective all of the time or be used in all types of contaminated sites. If the contamination runs too deep, or the concentration of toxic compounds is too high, then plants alone cannot efficiently remediate the soil (Cunningham et al., 1995).

\section{Phytoremediation of toxic metals}

Soils may become polluted with high concentration of toxic metals and their remediation may often involve excavation and removal of soil to secured landfills, an expensive technology that requires site restoration (Glick, 2003). Moreover, besides being an expensive and labour intensive effort, cleaning up contaminated sites has been accompanied by secondary environmental and legal problems. The phytoremediation of heavy metal contaminated soil basically involves the extraction or inactivation of these metals in soils (Lombi et al., 2001). However, some metals such as Pb are largely immobile in soil and their extraction rate is limited by solubility and diffusion to the root surface (Lombi et al., 2001). Conventional technologies suitable for water and soil remediation used in situ and ex situ are: pneumatic fracturing, soil flushing, solidification/stabilization, vitrification, chemical reduction/oxidation, soil washing and excavation. All these methods are cost prohibitive and often can generate secondary waste (Prasad, 2003). The use of several chelating agents, such as EDTA (ethylenediaminetetraacetic acid), EGTA (ethylene glycol-O,O'-bis-[2-amino-ethyl]N,N,N',N',-tetraacetic acid), EDDHA (ethylenediamine di(ohyroxyphenylacetic acid) and citric acid, has been developed to chemically enhance phytoextraction by mobilizing metals and increasing metal accumulation (Cooper et al., 1999). However, there is a potential risk of leaching of metals to the ground water and there is still a lack of detailed studies 
regarding the persistence of metal-chelating agent complexes in contaminated soils (Lombi et al., 2001).

It is also known that some metal contaminated soils are difficult to remediate and such soils are usually excavated and land filled. Sites can also be treated by acid leaching, physical separation of the contaminant or electrochemical processes (Cunningham et al., 1995). Moreover, the costs associated with soil remediation are variable and depend on the properties of the soil, the contaminants, site conditions and the volume of material to be remediated (Cunningham et al., 1995). Considering these limitations, phytoremediation is one innovative approach that offers more environmental benefits and a cost effective alternative.

In phytoextraction and phytomining, accumulated toxic metals in plant tissues are harvested for metal recovery and reuse. Normally, the plants termed hyperaccumulators are preferably used, since they have the ability to withstand and build up high concentrations of metals, when compared to other plants. These plants can be processed to recover the metals accumulated during the phytoremediation process (figure 1). Although it is cheaper than the conventional methods, phytoremediation is not an easy technology that consists of simply planting and growing some hyperaccumulating plants in the metal polluted area (Alkorta et al., 2004). It is in fact a highly technical strategy, requiring expert project designers with field experience that choose the proper species and cultivars for particular metals and regions (Alkorta et al., 2004). Research carried out with hyperaccumulator plant species has mainly focused attention on the physiological mechanisms by which the metal is taken up, transported and sequestrated, but little is know regarding the genetic basis of hyperaccumulation when compared with the genetic basis of metal tolerance (Pollard et al., 2002). There is evidence for a quantitative genetic variation controlling the ability of these plants to hyperaccumulate between and within populations (Pollard et al., 2002).

\section{Transgenic plants vs natural hyperaccumulators}

The ideal plant to make practical use of the phytoremediation technique must necessarily have a considerable capacity of metal uptake, accumulation and durability to reduce the length of treatment. Metal hyperaccumulator plants have been found in a wide range of families of vascular plants (Reeves and Baker, 2000; Prasad and Freitas 2003), but the Brassicaceae are well represented. However, most of the known metal hyperaccumulating plant species are metal selective, their growth rate is usually slow, they produce relatively small amounts of biomass and most of them can be used in their natural habitats only (Kamnev and van der Lelie, 2000). Moreover, the application of hyperaccumulator plants can be further limited because little is known about their agronomic characteristics, pest management, breeding potential and physiology, growing often in remote regions and in certain cases, their habitat is threatened by mining, development and others activities (Cunningham et al., 1995). Therefore, there appears to be a promising alternative in the development of transgenic plants with improved properties of metal uptake, accumulation and tolerance of toxicity. Such metal accumulation and tolerance could be enhanced by overexpressing natural or modified genes encoding antioxidant enzymes or those that are involved in the biosynthesis of glutathione and phytochelatins (figure 2).

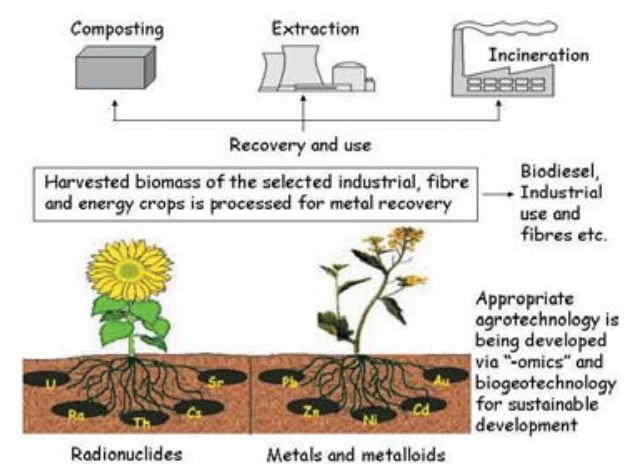

Figure 1. The approach of "green technology" for the clean up toxic metals, metalloids and radionuclides in the environment.

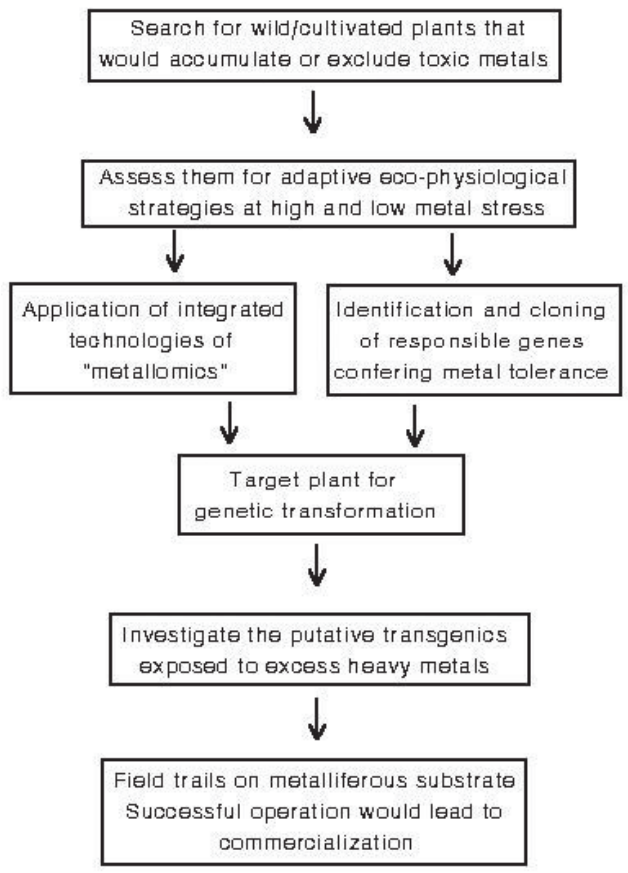

Figure 2. The use of genetic engineering to breed plants with superior phytoremediation potential (Modified after Karenlampi et al., 2000; Prasad, 2004b). 
From the preceding discussion it is apparent that in order to breed plants with superior phytoremediation potential, it is necessary that these plants have a high rate of biomass production and are sufficiently strong and competitive in the climate they are to be used for phytoremediation (Pilon-Smits and Pilon, 2002). Moreover, plants suitable for phytoremediation should possess the ability to accumulate the target metal in the above-ground parts, and to tolerate the metal concentration that is to be accumulated (Karenlampi et al., 2000). The overexpression of a gene encoding a rate limiting gene product would be expected to lead to a faster overall rate of the pathway and to more efficient phytoremediation (Pilon-Smits and Pilon, 2002). However, it must be considered that metals rarely occur alone in the environment and an adaptive tolerance may be essential for several metals simultaneously (Karenlampi et al., 2000).

\section{Transgenic plants}

Several researchers have already reported encouraging results using plants bioengineered with increased heavy metal tolerance and uptake of heavy metals for the purpose of phytoremediation.

An increasing number of attempts have been made to construct transgenic plants that are tolerant to the presence of high concentrations of toxic metals and thus may be suitable for phytoremediation (Berken et al., 2002; Rugh, 2004; Tong et al., 2004; Eapen and D'Souza, 2005). The majority of these novel plants have only been tested under limited laboratory conditions and very few have been grown in the field. In this section we will cover the general areas of plant metabolism that have already been investigated and discuss just a small number of the successes that have been obtained.

\section{S-metabolism, glutathione and phytochelatins}

Selenium (Se) is essential as a micronutrient for humans and animals but is toxic at medium to high concentrations. Se occurs naturally in soils as selenate and selenite and often as a pollutant, following the industrial use of coal. Se and sulphur (S) have very similar chemical properties and their uptake and assimilation as selenate and sulphate, to incorporation in proteins as selenomethionine and methionine, proceed through common pathways and are catalyzed by the same enzymes. A research group lead by Norman Terry and Elizabeth Pilon-Smits has considered the possibility of overexpressing a range of genes encoding key enzymes in sulphur metabolism, with the aim of obtaining selenium tolerant plants.
Indian mustard (Brassica juncea) plants overexpressing ATP sulphurylase were shown to have higher shoot $\mathrm{Se}$ concentrations and enhanced Se tolerance compared to wild type when grown in the presence of selenate in either hydroponic systems or soil (Pilon-Smits et al., 1999; Van Huysen et al., 2004). Interestingly, young transgenic plants that were overexpressing ATP sulphurylase, were more tolerant than the wild type to $\mathrm{As}(\mathrm{III}), \mathrm{As}(\mathrm{V}), \mathrm{Cd}$, $\mathrm{Cu}, \mathrm{Hg}$, and $\mathrm{Zn}$, but less tolerant to Mo and $\mathrm{V}$ (Wangeline et al., 2004). Other transgenic Indian mustard plants overexpressing cystathionine- $\gamma$-synthase (CGS) showed a higher Se volatilization rate, lower shoot Se levels, and higher Se tolerance than wild type grown in either soil or hydroponically (Van Huysen et al., 2003;2004).

Astragalus bisulcatus is a native plant that has the capacity to grow on Se containing soils and accumulate Se to high concentrations but it has a slow growth rate. It has been proposed that in A. bisulcatus selenocysteine methyltransferase (SMT) specifically methylates selenocysteine (SeCys) to produce the nonprotein amino acid methylselenocysteine MetSeCys, which causes a reduction in the intracellular concentrations of SeCys and selenomethionine (SeMet), thus preventing their incorrect insertion into protein. Indian mustard plants overexpressing the A. bisulcatus SMT gene, exhibited a greatly increased accumulation of MetSeCys and tolerance to Se compounds, in particular selenite (LeDuc et al., 2004).

$\mathrm{Cd}$ is a toxic element that normally occurs in low concentrations in soils, however the concentration can be significantly increased by activities such as zinc mining, iron foundries and the use of sewage sludge as a fertilizer in agriculture (Zhao et al., 2003). Cd may be detoxified in plants by a family of sulphur rich peptides termed phytochelatins (PCs) that are able to bind $\mathrm{Cd}$ and some other heavy metals (Cobbett and Goldsbrough, 2002). The peptides are structurally related to glutathione and contain a varying number (normally 2-5) of glutamate and cysteine, linked through the $\gamma$-carboxyl group of glutamate. Phytochelatin synthase (PCS) has been characterized as a specific $\gamma$-glutamyl cysteine dipeptidyl transpeptidase (EC 2.3.2.15) (Vatamaniuk et al., 2004), which carries out the conversion of glutathione to PCs, and has been shown to be activated by $\mathrm{Cd}$.

Various attempts have been made to increase the formation of PCs, by overexpressing genes encoding enzymes that could stimulate the synthesis of cysteine and glutathione. Cysteine synthase catalyses the last step in the assimila- 
tion of sulphate into the amino acid. Transgenic tobacco plants over-expressing cysteine synthase in the cytosol, had elevated concentrations of PCs, were more tolerant to $\mathrm{Cd}$, but did not accumulate the metal in the leaves (Harada et al., 2001). In contrast, Dominguez-Solis et al. (2004) overexpressed cysteine synthase in the cytosol of $A$. thaliana. One transgenic line was shown to be particularly resistant to $\mathrm{Cd}$ and to accumulate high concentrations in the leaves mainly in the trichomes. Transgenic tobacco plants over expressing cysteine synthase in either the cytosol or chloroplasts were more tolerant to metals such as $\mathrm{Cd}$, Se and $\mathrm{Ni}$. $\mathrm{F}_{1}$ plants with expression in both the cytosol and chloroplast exhibited a higher tolerance than the other transgenic lines and accumulated Cd in the shoots (Kawashima et al., 2004).

Indian mustard overexpressing the E. coli gshI gene encoding $\gamma$-glutamylcysteine synthetase $(\gamma$-ECS) exhibited increased tolerance to $\mathrm{Cd}$ and had higher concentrations of PCs and $\gamma$-GluCys, compared to the wild-type. When tested in a hydroponic system, $\gamma$-ECS plants grew better and accumulated Cd in the shoots (Zhu et al., 1999b). Transgenic Indian mustard containing the E. coli gshll gene encoding glutathione synthetase (GS) accumulated significantly more $\mathrm{Cd}$ than the wild type in the shoot and the plants showed enhanced tolerance to $\mathrm{Cd}$ at both the seedling and matureplant stages (Zhu et al., 1999a). Zhu et al. (1999b) concluded from the results obtained with the two types of transgenic plants, that under normal conditions that $\gamma$-ECS limits the rate of glutathione and $\mathrm{PC}$ synthesis, but that in the presence of $\mathrm{Cd} \gamma$-ECS is activated and that GS becomes rate limiting. When grown in contaminated soil, the thiol-overproducing transgenic $\gamma$-ECS and GS Indian mustard plants showed enhanced phytoextraction capacity, yet still produced the same shoot biomass as the wild type. As a result, the total shoot metal accumulation of the $\gamma$-ECS and GS transgenics were 1.5-fold higher for $\mathrm{Cd}$, and 1.5- to 2-fold higher for $\mathrm{Zn}$. Furthermore, the $\gamma$-ECS transgenics accumulated 2.4 to 3 -fold more $\mathrm{Cr}, \mathrm{Cu}$, and $\mathrm{Pb}$, relative to the wild type (Bennett et al., 2003).

Following the positive results obtained with overexpressing the enzymes involved in cysteine and glutathione synthesis, it was expected that overexpressing PCS would be even more successful, however this did not prove to be the case for Cd toxicity. When PCS was overexpressed in A. thaliana, the transgenic plants were shown to be hypersensitive to $\mathrm{Cd}$ and $\mathrm{Zn}$ but not to $\mathrm{Cu}$ (Lee et al., 2003b). In a similar series of experiments, overexpressing PCS in A. thaliana, Li et al. (2004) demonstrated that the transgenic plants were highly resistant to arsenic (As), accumulating 20-100 times more biomass on 250 and 300 $\mu \mathrm{M}$ arsenate, than the wild type. However again the PCS plants were hypersensitive to $\mathrm{Cd}$, despite the fact that they contained 2-6 fold higher concentrations of PCs. However, transgenic tobacco Nicotiana glauca expressing wheat PCS showed a slight increase in tolerance to Cd (Gisbert et al., 2003). These somewhat surprising results were discussed in detail by Li et al. (2004) and they concluded that "much is still to be learned about the processing of cadmium in Cd-PC peptide complexes".

\section{Metallothioneins}

Metallothioneins (MTs) are low molecular mass cysteine rich proteins that were originally isolated as $\mathrm{Cu}, \mathrm{Cd}$ and $\mathrm{Zn}$ binding proteins in mammals. There is now good evidence that four categories of these proteins occur in plants, which are encoded by at least seven genes in A. thaliana (Cobbett and Goldsbrough, 2002). A wide range of MT genes from various sources have been overexpressed in plants, these include human (Misra and Gedamu, 1989), mouse (Maiti et al., 1991; Pan et al., 1994), Chinese hamster (Hattori et al., 1994) and yeast (Hasegawa et al., 1997; Thomas et al., 2003). There was some variation in the range of $\mathrm{Cd}$ tolerance obtained. Metal uptake and accumulation in the shoots was not markedly altered, ranging from $70 \%$ less to $30 \%$ more than the wild type controls.

When a pea (Pisum sativum) MT gene PSMTA was expressed in A. thaliana, more $\mathrm{Cu}$ (several-fold in some plants) accumulated in the roots of transformed than of control plants (Evans et al., 1992). Similarly when a type 2 MT gene, tyMT, cloned from Cattail (Typha latifolia), a wetland plant with constitutional tolerance, was introduced into A. thaliana, the transgenic plant showed an increased tolerance to both $\mathrm{Cu}^{2+}$ and $\mathrm{Cd}^{2+}$ (Zhang et al., 2004). The $A$. thaliana metallothionein proteins AtMT2a and AtMT3 were introduced as fluorescent protein-fused forms into the guard cells of Vicia faba. The MTs protected guard cell chloroplasts from degradation upon exposure to $\mathrm{Cd}$, by reducing the presence of reactive oxygen species. It was concluded that the $\mathrm{Cd}$ stays bound to the MT in the cytoplasm and is not sequestered into the vacuole, as occurs when Cd is detoxified by PCs (Lee at al., 2004).

\section{Transporters}

There has been considerable interest in the possibility of manipulating transporters within plants in order to achieve different objectives, these include exclusion of a toxic metal ion, 
transporting the metal into the apoplastic space and transporting the metal into the vacuole where it would be less likely to exert a toxic effect (Tong et al., 2004). In this article we will only cover a little of the extensive work that has been carried out.

Lee et al. (2003a) transformed $A$. thaliana plants with the $E$. coli gene, ZntA, which encodes a $\mathrm{Pb}(\mathrm{II}) / \mathrm{Cd}(\mathrm{II}) / \mathrm{Zn}(\mathrm{II})$ transporter. The ZntA-transgenic plants grew better than the wild-type plant in $\mathrm{Pb}, \mathrm{Cd}$ and $\mathrm{Zn}$-containing medium. The shoots of the transgenic plants exhibited decreased $\mathrm{Pb}$ and $\mathrm{Cd}$ contents, whereas transgenic protoplasts showed lower accumulation of $\mathrm{Cd}$ and faster release of pre-loaded $\mathrm{Cd}$ than wild-type protoplasts. Lee et al. (2003a) proposed that the ZntA-transgenic plants excluded the metal ions at the cellular level by pumping them from the plasma membrane to the extracellular space.

The overexpression of the AtHMA4 gene, which encodes a $A$. thaliana $\mathrm{P}-1 \mathrm{~B}-\mathrm{ATP}$ ase $\mathrm{Zn}$ and $\mathrm{Cd}$ transporter, improved the growth of both primary and secondary roots in the presence of toxic concentrations of $\mathrm{Zn}, \mathrm{Cd}$ and Co. A determination of metal content demonstrated that the overexpressing lines, when exposed to toxic concentrations of $\mathrm{Zn}$ or $\mathrm{Cd}$, translocated these metals at a greater extent to the shoot, compared to the control plants, an important criteria for phytoremediation. In contrast, the metal level was found to be rather similar in roots, indicating that the metal uptake by the roots compensated for the increased metal translocation to the shoot (Verret et al., 2004).

The vacuole is generally considered to be the main storage site for metals in yeast and plant cells and there is evidence that phytochelatin-metal complexes are pumped into the vacuole. The best characterized of the known vacuolar transporters and channels involved in metal tolerance is YCF1 from Saccharomyces cerevisiae. YCF1 is a MgATP-energized glutathione $S$-conjugate transporter responsible for vacuolar sequestration of compounds after their $S$-conjugation with glutathione. Song et al. (2003) overexpressed the YCF1 gene in $A$. thaliana and the YCF1 proteins were found to be associated with the tonoplast and the plasma membrane. The vacuoles of the YCF1-transgenic plants exhibited a 4-fold higher rate of glutathione-Cd uptake than those of wild-type plants, indicating that expression of $Y C F 1$ strongly increases $\mathrm{Cd}$ transport activity The transgenic plants showed improved resistance to both $\mathrm{Cd}$ and $\mathrm{Pb}$ and elevated metal content, characteristics desirable for phytoremediation.

Other transporter proteins that could be of value include: - the A. thaliana antiporter CAX2 (Hirschi et al., 2000), LCT1, a nonspecific transporter for $\mathrm{Ca}^{2+}, \mathrm{Cd}^{2+}, \mathrm{Na}^{+}$and $\mathrm{K}^{+}$
(Antosiewicz and Hennig, 2004), the Thlaspi caerulescens heavy metal ATPase, TcHMA4 (Papoyan and Kochian, 2004), a novel family of cysteine rich membrane proteins that mediate Cd resistance in A. thaliana (Song et al., 2004) and AtMRP3, an ABC transporter (Bovet et al., 2005).

It can be seen from the above account of work that has been already carried out, that there are a large number of possibilities to improve the ability of plants to withstand the stresses of high concentrations of toxic metals and also to accumulate them. Additional work not mentioned includes overexpressing genes encoding: - ACC deaminase (Grichko et al., 2000), mercuric ion reductase (Che et al., 2003), arsenate reductase (Dhankher et al., 2003), aldose/aldehyde reductase (Hegedüs et al., 2004) and enzymes of histidine biosynthesis (Wycisk et al., 2004).

Clearly there may be some opportunity to combine some of these genes in fast growing species, but more importantly the plants need to be tested under carefully regulated environmental conditions.

\section{Natural hyperaccumulators}

Natural metal hyperaccumulators plants can accumulate and tolerate greater metal concentrations in shoots than those usually found in non-accumulators, without visible symptoms. According to Baker and Brooks (1989), the minimum threshold tissue concentrations for $\mathrm{Co}, \mathrm{Cu}, \mathrm{Cr}, \mathrm{Pb}$ or $\mathrm{Ni}$ hyperaccumulators should be $0.1 \%$ dry weight, while for $\mathrm{Zn}$ or Mn the threshold is $1 \%$. Over 400 hyperaccumulator plants have been reported and include members of the Asteraceae, Brassicaceae, Caryophyllaceae, Cyperaceae, Cunouniaceae, Fabaceae, Flacourtiaceae, Lamiaceae, Poaceae, Violaceae, and Euphobiaceae. The Brassicaceae is a very important group when heavy metal accumulation is concerned, with several species being able to hyperaccumulate more than one metal (Prasad and Freitas, 2003).

Pistia stratiotes was examined in the presence of several distinct heavy metals separately, in order to determine the ability of the plant to tolerate and accumulate the metals tested and for eventual use for phytoremediation of waste water or natural water bodies polluted with these heavy metals (Odjegba and Fasidi, 2004). P. stratiotes exhibited different patterns of response to $\mathrm{Ag}, \mathrm{Cd}, \mathrm{Cr}, \mathrm{Cu}, \mathrm{Hg}, \mathrm{Ni}, \mathrm{Pb}$ and $\mathrm{Zn}$, and although concentrations as high as $5 \mathrm{mM}$ resulted in distinct levels of growth inhibition and biomass production, all the elements accumulated at high concentrations mainly in the root system. Furthermore, this plant species exhibited the highest tolerance index to $\mathrm{Zn}$ and the lowest to $\mathrm{Hg}$ (Odjegba and Fasidi, 2004). 
Spartina plants have been shown to be 3-fold more tolerant to $\mathrm{Hg}$ than tobacco plants, due to an ability to absorb organic $\mathrm{Hg}$ and transform it into an inorganic form $\left(\mathrm{Hg}^{+}, \mathrm{Hg}^{2+}\right)$. The inorganic $\mathrm{Hg}$ then accumulates in the underground parts of the plants and is transferred back to the soil by diffusion and permeation, indicating that this species may be used in the phytoremediation of a $\mathrm{Hg}$ polluted environment (Tian et al., 2004). According to Bennicelli et al. (2004), the water hyperaccumulator fern Azolla caroliniana Willd. (Azollaceae) has the capacity to purify waters polluted by $\mathrm{Hg}$ and $\mathrm{Cr}$ by accumulation of these heavy metals in its tissues.

Helianthus annuus has been shown to concentrate $\mathrm{Pb}$ in the leaf and stem indicating that it has the prerequisites of a hyperaccumulator plant that could be used in the restoration of abandoned mines and factories sites contaminated with elevated Pb levels in the soil (Boonyapookana et al., 2005). In an almost similar manner, Hemidesmus indicus has also been shown to be a $\mathrm{Pb}$ hyperaccumulating plant species, but the heavy metal was mainly accumulated in roots and shoots (Chandra et al., 2005), exhibiting a high potential for use in the phytoremediation of industrial areas contaminated with this metal. The hyperaccumulator Sesbania drummondii is a plant species that has been shown to predominantly accumulate $\mathrm{Pb}$ as lead acetate in roots and leaves, although lead sulfate and sulfide have also been detected in leaves, whereas lead sulfide was detected in root samples (Sharma et al., 2004). These results have indicated that $S$. drummondii is able to biotransform lead nitrate in the nutrient solution to lead acetate and sulfate in its tissues and the complexation with acetate and sulfate may be a lead detoxification strategy in this plant species (Sharma et al., 2004).

Studies related to As accumulation in Lemna gibba have demonstrated that this plant species can be a preliminary bioindicator for As transfer from substrate to plants, indicating its use to monitor the transfer of arsenic from lower to higher trophic levels in abandoned mine sites (Mkandawire and Dudel, 2005). Moreover, L. gibba can be used for As phytoremediation of mine tailing waters because of its high accumulation capacity (Mkandawire and Dudel, 2005). Pteris vittata can hyperaccumulate As from naturally contaminated soils, but may be suitable for phytoremediation only in the moderately contaminated soils (Caille et al., 2004). In addition to $P$. vittata, $P$. cretica, $P$. longifolia and P. umbrosa are also able to hyperaccumulate As to a similar extent (Zhao et al., 2002).

Broadhurst et al. (2004) have development commercially viable phytoremediation/phytomining technologies employing Alyssum Ni-hyperaccumulator species, where the majority of $\mathrm{Ni}$ is stored either in the leaf epidermal cell vacuoles, or in the basal portions of the numerous stellate trichomes. The metal concentration in the trichome basal compartment was the highest ever reported for healthy vascular plant tissue, approximately $15-20 \%$ dry weight (Broadhurst et al., 2004).

Solanum nigrum and Conyza canadensis have not only been shown to accumulate high concentration of $\mathrm{Cd}$, but also to be tolerant to the combined action of $\mathrm{Cd}, \mathrm{Pb}, \mathrm{Cu}$ and $\mathrm{Zn}$ (Wei et al., 2004). The hyperaccumulator Thlaspi caerulescens J. \& C. Presl. has a high Cd-accumulating capability, acquiring $\mathrm{Cd}$ from the same soil pools as non-accumulating species, by very efficient mechanisms (Schwartz et al., 2003). Thus, T. caerulescens may be used as a tool to efficiently reduce the availability of $\mathrm{Cd}$ in soils, providing appropriate populations are used (Schwartz et al., 2003). Moreover, Arabis gemmifera is a hyperaccumulator of $\mathrm{Cd}$ and $\mathrm{Zn}$, with phytoextraction capacities almost equal to Thlaspi caerulescens (Kubota and Takenaka, 2003) and plants of the mined ecotype of Sedum alfredii Hance have a greater ability to tolerate, transport, and accumulate $\mathrm{Cd}$, when compared to the non-mined ecotype (Xiong et al., 2004).

Al hyperaccumulators have also been described and can include mainly woody, perennial taxa from tropical regions. These hyperaccumulator plants can take up aluminum in their aboveground tissues in quantities above 1000 ppm 0.1 $\%$ dry weight, exceeding those present in the soil or in the nonaccumulating plant species growing nearby (Jansen et al., 2002). These hyperaccumulators are particularly common in basal branches of fairly advanced groups such as rosids (Myrtales, Malpighiales, Oxalidales) and asterids (Cornales, Ericales, Gentianales, Aquifoliales) and in 27 other families, $\mathrm{Al}$ hyperaccumulation is restricted to subfamilies, tribes, or genera (Jansen et al., 2002).

In the case of Se and Mn, Stanleya pinnata is a potentially useful species for phytoremediation due to its broad adaptation to semi-arid western U. S. soils and environments, and its uptake, metabolism and volatilization of Se (Parker et al., 2003), whereas an Australian native hyperaccumulator of Mn, Austromyrtus bidwillii (Benth.) Burrett (Myrtaceae) has been identified (Bidwell et al., 2002). Phytolacca acinosa Roxb. (Phytolaccaceae) is a Mn hyperaccumulator species which grows rapidly, has substantial biomass, wide distribution and a broad ecological amplitude, demonstrating its potential for use in the phytoremediation of $\mathrm{Mn}$ contaminated soils (Xue et al., 2004). 
Understanding the mechanisms of rhizosphere interaction, uptake, transport and sequestration of metals in hyperaccumulator plants will lead to designing novel transgenic plants with improved remediation traits (Eapen and Souza, 2005). Moreover, the selection and testing of multiple hyperaccumulator plants could enhance the rate of phytoremediation, making this process a successful one for bioremediation of environmental contamination (Suresh and Ravishankar, 2004).

\section{Advantages and limitations of phytoremediation}

Several processes can limit the performance of plants in phytoremediation, such as the availability of the toxic metal ions in the soil for uptake by plant roots, the rate of uptake of the contaminants by plant roots, their translocation from roots to shoots and the extent of tolerance, or the rate of chemical transformation into less toxic, possibly volatile compounds (Prasad, 2003) (Table 2).

Although the use of transgenic plants as phytoremediators is showing increasing potential for soils contaminated with toxic metals, possible risks should be considered, including the uncontrolled spread of the transgenic plants due to interbreeding with populations of wild relatives. Moreover, the transformation of metals into forms more bioavailable could increase the exposure of wildlife and humans to metals. However, the risk of metal accumulation in plant shoots that can be ingested by the wildlife, can be minimized by the reduction of the growth period and thus exposure of the transgenic plants. Furthermore, it is important that in the case of harvesting crop plants normally used to feed livestock and humans, the translocation of the toxic elements to the seeds is avoided at all costs.

Full utilization of plant resources after they have been used for phytoremediation is an unsolved problem. Therefore the testing of the plants used in phytoremediation is necessary and may support their continuous use in contaminated soils. For instance, Elsholtzia argyi flowers are used as fragrances and antiseptics due to the perfume ingredient and antibacterial components existing in their essential oils, and the analysis of these plants in $\mathrm{Pb} / \mathrm{Zn}$ mined area, where they normally occur revealed that they can be safely exploited (Peng and Yang, 2005).

While phytoremediation processes hold a great promise as a way to remediate contaminated soils, there are disadvantages and limitations that must be carefully considered.

\section{CONCLUDING REMARKS AND OUTLOOK}

It is evident that phytoremediation has benefits to restore balance to a stressed environment, but it is important to proceed with caution. The study and use of genetic modifica-

Table 2. Advantages and limitations of some of the sub-processes of phytoremediation (Prasad 2004b).

\begin{tabular}{|l|l|}
\hline \multicolumn{1}{|c|}{ Advantage } & \multicolumn{1}{|c|}{ Phytoextraction } \\
\hline \multicolumn{2}{|c|}{ Phytostabilization } \\
\hline $\begin{array}{l}\text { The plant must be able to produce abundant biomass in short } \\
\text { time. E.g. in green house experiments, gold was harvested from } \\
\text { plants (Anderson et al., 1998). }\end{array}$ & $\begin{array}{l}\text { Metal hyperaccumulators are generally slow-growing and bio- } \\
\text { productivity is rather small and shallow root systems. Phytomass after } \\
\text { process must be disposed off properly. }\end{array}$ \\
\hline \multicolumn{2}{|c|}{ Phytovolatilization } \\
\hline $\begin{array}{l}\text { It circumvents the removal of soil, low cost and is less disruptive } \\
\text { and enhances ecosystem restoration/re-vegetation. }\end{array}$ & $\begin{array}{l}\text { Often requires extensive fertilization or soil modification using } \\
\text { amendments, long-term maintenance is needed to prevent leaching. }\end{array}$ \\
\hline $\begin{array}{l}\text { Contaminant/Pollutant will be transformed in to less-toxic forms. } \\
\text { E.g. elemental mercury and dimethyl selenite gas. Atmospheric } \\
\text { processes such as photochemical degradation for rapid } \\
\text { decontamination/transformation. }\end{array}$ & $\begin{array}{l}\text { The contaminant or a hazardous metabolite might accumulate in } \\
\text { vegetation and be passed on in later products such as fruit or lumber. } \\
\text { Low levels of metabolites have been found in plant tissue. }\end{array}$ \\
\hline \multicolumn{2}{|c|}{ Phytofiltration/rhizofiltration } \\
\hline $\begin{array}{l}\text { It can be either in situ (floating rafts on ponds) or ex situ (an } \\
\text { engineered tank system); terrestrial or aquatic. }\end{array}$ & $\begin{array}{l}\text { pH of the medium to be monitored continually for optimizing uptake } \\
\text { of metals; chemical speciation and interactions of all species in the } \\
\text { influent need be understood; functions like a bioreactor and intensive } \\
\text { maintenance is needed. }\end{array}$ \\
\hline
\end{tabular}


tions must be performed in order to determine the true costs and benefits of this technology to the ecosystem as a whole, before is to be applied to a larger scale. Progress in the field of molecular genetics, will allow the analysis of metal hyperaccumulator plants and should provide new insights into metabolic detoxification processes and identify tolerance genes, thus providing considerable more information about the genomes of these model organisms.

Advances in other methods involving analysis of "omics" technologies could further reveal the non-targeted identification of all gene products in a specific biological sample, which could be followed by a refined analysis of quantitative dynamics in biological systems. The genomics can accelerate the discovery of genes that confer key traits, allowing their modification. In addition, metabolomics can provide biochemical and physiological knowledge about network organization in plants subject to toxic metal stress, providing a much more details understanding of the molecular basis of hyperaccumulation.

Approaches allowing recombination hotspots to be highlighted will further aid plant breeding efforts. Many signalling pathways and proteins can contribute to the cellular stress response, and the identification of the key ones within the stress response network is essential. The development of DNA and RNA microarray chip technologies in systematic genome mapping, sequencing, functioning and experimentation may allow the identification and genotyping of mutations and polymorphisms, allowing better insight into structure-function interaction of genome complexity under toxic metal stress. Moreover, Mitogen-Activated Protein Kinase (MAPK) pathways are activated in response to metal stress, which encourages new strategies for improving plant tolerance to heavy metals and phytoremediation.

Molecular genetics approaches such as insertion mutagenesis involving populations of T-DNA, can be used to identify genes involved in hyper-accumulation or transposon tagged plants screened to identify mutants impaired in the ability to accumulate metals (Pollard et al., 2002). Recently, considerable progress has been made in identifying plant genes encoding metal ion transporters with important functions in cation transport and homeostasis (Papoyan and Kochian, 2004; Weber et al., 2004). Modern molecular techniques, bioinformatics and computational techniques are effective tools for detailed structure-function genome analysis. It is clear that both fundamental and applied research must be carried out in association, since the lack of the basic understanding will make it difficult to exploit many of the recent advances in plant molecular biology.
Phytoremediation technology is still in its early development stages and full scale applications are still limited. The results already obtained have indicated that the plants are effective and could be used in toxic metal remediation. Although it appears to be common sense among scientists, engineers, and regulators about the more widespread future use of this technique, it is important that public awareness about this technology is considered and clear and precise information is made available to the general public to enhance its acceptability as a global sustainable technology to be widely used.

As this article was being completed, we were made aware of a review by Pilon-Smits (2005) that had become available and we recommend it to those with a serious interest in phytoremediation.

Acknowledgments: The authors wish to thank the continuous support over the years by the Fundação de Amparo a Pesquisa do Estado de São Paulo (FAPESP), Brazil and The British Council.

\section{REFERENCES}

Alkorta I, Hernández-Allica J, Becerril JM, Amezaga I, Albizu I, Garbisu C (2004) Recent findings on the phytoremediation of soils contaminated with environmentally toxic heavy metals and metalloids such as zinc, cadmium, lead, and arsenic. Rev. Environ. Sci. Biotechnol. 3:71-90.

Anderson CWN, Brooks RR, Stewart RB, Simcock R (1998) Harvesting a crop of gold in plants. Nature 395: 553-554.

Antosiewicz DM, Hennig J (2004) Overexpression of LCT1 in tobacco enhances the protective action of calcium against cadmium toxicity. Environ. Pollut. 129:237-245.

Archer MJG, Caldwell RA (2004) Response of six Australian plant species to heavy metal contamination at an abandoned mine site. Water Air Soil Poll. 157:257-267.

Baker AJM, Brooks RR (1989) Terrestrial higher plants which hyperaccumulate metallic elements- a review of their distribution, ecology and phytochemistry. Biorecovery 1:81-126.

Bennett LE, Burkhead JL, Hale KL, Terry N, Pilon M, PilonSmits EAH (2003) Analysis of transgenic Indian mustard plants for phytoremediation of metal-contaminated mine tailings. J. Env. Qual. 32:432-440.

Bennicelli R, Stepniewska Z, Banach A, Szajnocha K, Ostrowski J (2004) The ability of Azolla caroliniana to remove heavy metals ( $\mathrm{Hg}(\mathrm{II}), \mathrm{Cr}(\mathrm{III}), \mathrm{Cr}(\mathrm{VI}))$ from municipal waste water. Chemosphere 55:141-146.

Berken A, Mulholland MM, LeDuc DL, Terry N (2002) Genetic engineering of plants to enhance selenium phytoremediation. Crit. Rev. Plant Sci. 21:567-582. 
Bidwell SD, Woodrow IE, Batianoff GN, Sommer-Knudsen J (2002) Hyperaccumulation of manganese in the rainforest tree Austromyrtus bidwillii (Myrtaceae) from Queensland, Australia. Funct. Plant Biol. 29:899-905.

Boonyapookana B, Parkplan P, Techapinyawat S, DeLaune RD, Jugsujinda A (2005) Phytoaccumulation of lead by sunflower (Helianthus annuus), tobacco (Nicotiana tabacum), and vetiver (Vetiveria zizanioides). J. Environ. Sci. Heal. A 40:117-137.

Bovet L, Feller U, Martinoia E (2005) Possible involvement of plant ABC transporters in cadmium detoxification: a cDNA sub-microarray approach. Environ Int. 31:263-267.

Broadhurst CL, Chaney RL, Angle JS, Maugel TK, Erbe EF, Murphy CA (2004) Simultaneous hyperaccumulation of nickel, manganese, and calcium in Alyssum leaf trichomes. Environ. Sci. Technol.38:5797-5802.

Caille N, Swanwick S, Zhao FJ, McGrath SP (2004) Arsenic hyperaccumulation by Pteris vittata from arsenic contaminated soils and the effect of liming and phosphate fertilisation. Environ. Pollut. 132:113-120.

Chandra Sekhar K, Kamala CT, Chary NS, Balaram V, Garcia G (2005) Potential of Hemidesmus indicus for phytoextraction of lead from industrially contaminated soils. Chemosphere 58:507-514.

Che DS, Meagher RB, Heaton ACP, Lima A, Rugh CL, Merkle SA (2003) Expression of mercuric ion reductase in Eastern cottonwood (Populus deltoides) vbconfers mercuric ion reduction and resistance. Plant Biotech. J. 1:311-319.

Cobbett C, Goldsbrough P (2002) Phytochelatins and metallothioneins: Roles in heavy metal detoxification and homeostasis. Ann. Rev. Plant Biol. 53:159-182.

Cooper EM, Sims JT, Cunningham SD, Huang JW, Berti WR (1999) Chelate-assisted phytoextraction of lead from contaminated soils. J. Environ. Qual. 28:1709-1719.

Cunningham SD, Berti WR, Huang JW (1995) Phytoremediation of contaminated soils. TIBTECH 13: 393-397.

Dhankher OP, Shasti NA, Rosen BP, Fuhrmann M, Meagher RB (2003) Increased cadmium tolerance and accumulation by plants expressing bacterial arsenate reductase. New Phytol. 159:431-441.

Dominguez-Solis JR, Lopez-Martin MC, Ager FJ, Ynsa MD, Romero LC, Gotor C (2004) Increased cysteine availability is essential for cadmium tolerance and accumulation in Arabidopsis thaliana. Plant Biotechnol. J. 2:469-476.

Eapen S, D'Souza SF (2005) Prospects of genetic engineering of plants for phytoremediation of toxic metals. Biotech. Adv. 23:97-114.

Evans KM, Gatehouse JA, Lindsay WP, Shi J, Tommey AM, Robinson NJ (1992) Expression of the pea metallothioneinlike gene PSMTA in Escherichia coli and Arabidopsis thaliana and analysis of trace metal ion accumulation: implications for PsMTA function. Plant Mol. Biol. 20: 1019-1028.

Gisbert C, Ros R, De Haro A, Walker DJ, Bernal MP, Serrano R, Navarro-Aviñó J (2003) A plant genetically modified that accumulates $\mathrm{Pb}$ is especially promising for phytoremediation. Biochem. Biophys. Res. Commun. 303: 440-445.

Glick BR (2003) Phytoremediation: synergistic use of plants and bacteria to clean up the environment. Biotechnol. Adv. 21:383-393.

Grichko VP, Filby B, Glick BR (2000) Increased ability of transgenic plants expressing the bacterial enzyme ACC deaminase to accumulate $\mathrm{Cd}, \mathrm{Co}, \mathrm{Cu}, \mathrm{NI}, \mathrm{Pb}$, and $\mathrm{Zn}$. J. Biotechnol. 81:45-53.

Harada E, Choi YE, Tsuchisaka A, Obata H, Sano H (2001) Transgenic tobacco plants expressing a rice cysteine synthase gene are tolerant to toxic levels of cadmium. J. Plant Physiol. 158:655-661.

Hasegawa I, Terada E, Sunairi M, Wakita H, Shinmachi F, Noguchi A, Nakajima M, Yazaki J (1997) Genetic improvement of heavy metal tolerance in plants by transfer of the yeast metallothionein gene (CUP1). Plant Soil 196:277-281.

Hattori J, Labbé H, Miki BL (1994) Construction and expression of a metallothionein- $\beta$-glucuronidase gene fusion. Genome 37:508-512.

Hegedüs A, Erdei S, Janda T, Tóth E, Horváth G, Dudits D (2004) Transgenic tobacco plants overproducing alfalfa aldose/aldehyde reductase show higher tolerance to low temperature and cadmium stress. Plant Sci. 166:13291333.

Hirschi ED, Korenkey, VD, Wilganewski NI, Wagner GI (2000) Expression of Arabidopsis CAX2 in tobacco. Altered metal accumulation and increased manganese tolerance. Plant Physiol. 124:128-133.

Jansen S, Broadley MR, Robbrecht E, Smets E (2002) Aluminum hyperaccumulation in angiosperms: A review of its phylogenetic significance. Bot. Rev. 68:235-269.

Kamnev AA, van der Lelie D (2000) Chemical and biological parameters as tools to evaluate and improve heavy metal phytoremediation. Bioscience Rep. 20:239-258.

Karenlampi S, Schat H, Vangronsveld J, Verkleij JAC, van der Lelie D, Mergeay M, Tervahauta AI (2000) Genetic engineering in the improvement of plants for phytoremediation of metal polluted soils. Environ. Pollut. 107:225-231.

Kawashima CG, Noji M, Nakamura M, Ogra Y, Suzuki KT, Saito K (2004) Heavy metal tolerance of transgenic tobacco plants over-expressing cysteine synthase. Biotechnol. Lett. 26:153-157.

Kubota H, Takenaka C (2003) Arabis gemmifera is a hyperaccumulator of $\mathrm{Cd}$ and $\mathrm{Zn}$. Int. J. Phytoremediation 5:197-120.

Lasat MM (2000) Phytoextraction of metals from contaminated sites - a critical review of plant/soil/metal interaction and assessment of pertinent agronomic issues. J. Hazard Substance Res. 2:1-25.

LeDuc DL, Tarun AS, Montes-Bayon M, Meija J, Malit MF, Wu CP, AbdelSamie M, Chiang CY, Tagmount A, DeSouza M, Neuhierl B, Bock A, Caruso J, Terry N (2004) Overexpression of selenocysteine methyltransferase in Arabidopsis and Indian mustard increases selenium tolerance and accumulation. Plant Physiol. 135:377-383. 
Lee J, Bae H, Jeong J, Lee JY, Yang YY, Hwang I, Martinoia E, Lee Y (2003a) Functional expression of a bacterial heavy metal transporter in Arabidopsis enhances resistance to and decrease uptake of heavy metals. Plant Physiol. 133:589596.

Lee J, Shim D, Song WY, Hwang I, Lee Y (2004) Arabidopsis metallothioneins $2 \mathrm{a}$ and 3 enhance resistance to cadmium when expressed in Vicia faba guard cells. Plant Mol. Biol. 54:805-815.

Lee S, Moon JS, Ko TS, Petros D, Goldsbrough PB, Korban SS (2003b) Overexpression of Arabidopsis phytochelatin synthase paradoxically leads to hypersensitivity to cadmium stress. Plant Physiol. 131:656-663.

Li Y, Dhankher OP, Carreira L, Lee D, Chen A, Schroeder JI, Balish RS, Meagher RB (2004) Overexpression of phytochelatin synthase in Arabidopsis leads to enhanced arsenic tolerance and cadmium hypersensitivity. Plant Cell Physiol. 45:1787-1797.

Lombi E, Zhao FJ, Dunham SJ, MacGrath SP (2001) Phytoremediation of heavy metal-contaminated soils: Natural hyperaccumulation versus chemically enhanced phytoextraction. J. Environ. Qual. 30:1919-1926.

Maiti IB, Hunt AG, Wagner GJ, Yeargan R, Hunt AG (1991) Light inducible and tissue specific expression of a chimeric mouse metallothionein cDNA gene in tobacco. Plant Sci. 76:99-107.

Misra S, Gedamu L (1989) Heavy metal tolerant transgenic Brassica napus L. and Nicotiana tabacum L. plants. Theor. Appl. Genet. 78:161-168.

Mkandawire M, Dudel EG (2005) Accumulation of arsenic in Lemna gibba L. (duckweed) in tailing waters of two abandoned uranium mining sites in Saxony, Germany. Sci. Total Environ. 336:81-89.

Newman LA, Reynolds CM (2004) Phytodegradation of organic compounds. Curr. Opin. Biotech. 15:225-230.

Odjegba VJ, Fasidi IO (2004) Accumulation of trace elements by Pistia stratiotes: implications for phytoremediation. Ecotoxicology 13:637-646.

Pan AH, Yang M, Tie F, Li L, Che Z, Ru B (1994) Expression of mouse metallothionein-I gene confers cadmium resistance in transgenic tobacco plants. Plant Mol. Biol. 24:341351.

Papoyan A, Kochian LV (2004) Identification of Thlaspi caerulescens genes that may be involved in heavy metal hyperaccumulation and tolerance. Characterization of a novel heavy metal transporting ATPase. Plant Physiol. 136:3814-3823.

Parker DR, Feist LJ, Varvel TW, Thomason DN, Zhang YQ (2003) Selenium phytoremediation potential of Stanleya pinnata. Plant Soil 249:157-165.

Peng HY, Yang XE (2005) Volatile constituents in the flowers of Elsholtzia argyi and their variation: a possible utilization of plant resources after phytoremediation. J Zhejiang Univ. Sci. 6:91-95.

Pilon-Smits E (2005) Phytoremediation. Annu. Rev. Plant Biol. 56:15-39.

Pilon-Smits E, Pilon M (2002) Phytoremediation of metals using transgenic plants. Crit. Rev. Plant Sci. 21:439-456.
Pilon-Smits EAH, Hwang S, Lytle CM, Zhu Y, Tai JC, Bravo RC, Chen Y, Leustek T, Terry N (1999) Overexpression of ATP sulfurylase in indian mustard leads to increased selenate uptake, reduction and tolerance. Plant Physiol. 119:123-132.

Pollard AJ, Powell KD, Harper FA, Smith JAC (2002) The genetic basis of metal hyperaccumulation in plants. Crit. Rev. Plant Sci. 21:539-566.

Prasad MNV (2004a) Heavy metal stress in plants: from molecules to ecosystems. $2^{\text {nd }}$ edn. Springer-Verlag Heidelberg Narosa New Delhi.

Prasad MNV (2004b) Phytoremediation of metals in the environment for sustainable development. Proceedings of the Indian National Science Academy 70:71-98.

Prasad MNV (2003) Phytoremediation of metal-polluted ecosystems: hype for commercialization. Russ. J. Plant Physiol. 50:686-700.

Prasad MNV, Freitas H (2003) Metal hyperaccumulation in plants - Biodiversity prospecting for phytoremediation technology. Electronic Journal of Biotechnology 6:275321. Online electronic journal http://www. ejbiotechnology. info/content/ vol6/ issue 3/index.html

Reeves RD, Baker AJM (2000) Metal-accumulating plants. In: Raskin I, Ensley BD (eds), Phytoremediation of Toxic Metals, pp. 193-229. Jonh Wiley, NY.

Rugh CL (2004) Prospects of genetic engineering of plants for phytoremediation of toxic metals Genetically engineered phytoremediation: one man's trash is another man's transgene. Trends Biotech. 22:496-498.

Sharma NC, Gardea-Torresdey JL, Parsons J, Sahi SV (2004) Chemical speciation and cellular deposition of lead in Sesbania drummondii. Environ. Toxicol. Chem. 23:20682073.

Schwartz C, Echevarria G, Morel JL (2003) Phytoextraction of cadmium with Thlaspi caerulescens. Plant Soil 24:27-35.

Singh OV, Jain RK (2003) Phytoremediation of toxic aromatic pollutants from soil. Appl. Microbiol. Biotech. 63:128135.

Song W-Y, Martinoia E, Lee J, Kim D, Kim D-Y, Vogt E, Shim D, Choi KS, Hwang I, Lee Y (2004) A novel family of CysRich membrane proteins mediates cadmium resistance in Arabidopsis. Plant Physiol. 135:1027-1039.

Song W-Y, Sohn EJ, Martinoia E, Lee YJ, Yang YY, Jasinski M, Forestier C, Hwang I, Lee Y (2003) Engineering tolerance and accumulation of lead and cadmium in transgenic plants. Nature Biotech. 21:914-919.

Suresh B, Ravishankar GA (2004) Phytoremediation - A novel and promising approach for environmental clean-up. Crit. Rev. Biotechnol. 24:97-124.

Thomas JC, Davies EC, Malick FK, Endreszl C, Williams CR, Abbas M, Petrella S, Swisher K, Perron M, Edwards R, Ostenkowski P, Urbanczyk N, Wiesend WN, Murray KS (2003) Yeast metallothionein in transgenic tobacco promotes copper uptake from contaminated soils. Biotech. Prog. 19:273-280.

Tian JL, Zhu HT, Yang YA, He YK (2004) Organic mercury tolerance, absorption and transformation in Spartina plants. 
Zhi Wu Sheng Li Yu Fen Zi Sheng Wu Xue Xue Bao 30: 577-582.

Tong YP, Kneer R, Zhu YG (2004) Vacuolar compartmentalization: a second-generation approach to engineering plants for phytoremediation. Trends Plant Sci. 9: 7-9.

Van Huysen T, Abdel-Ghany S, Hale KL, LeDuc D, Terry N, Pilon-Smits EAH (2003) Overexpression of cystathioninegamma-synthase enhances selenium volatilization in Brassica juncea. Planta 218:71-78.

Van Huysen T, Terry N, Pilon-Smits EAH (2004) Exploring the selenium phytoremediation potential of transgenic Indian mustard overexpressing ATP sulfurylase or cystathionine$\gamma$-synthase. Int. J. Phytoremed. 6:111-118.

Vatamaniuk OK, Mari S, Lang A, Chalasani S, Demkiv LO, Rea PA (2004) Phytochelatin synthase, a dipeptidyltransferase that undergoes multisite acylation with gammaglutamylcysteine during catalysis - Stoichiometric and site-directed mutagenic analysis of Arabidopsis thaliana PCS1-catalyzed phytochelatin synthesis. J. Biol. Chem. 279:22449-22460.

Verret F, Gravot A, Auroy P, Leonhardt N, David P, Nussaume L, Vavasseur A, Richaud P (2004) Overexpression of AtHMA4 enhances root-to-shoot translocation of zinc and cadmium and plant metal tolerance. FEBS Lett. 576: 306-312.

Wang QR, Cui YS, Liu XM, Dong YT, Christie P (2003) Soil contamination and uptake of heavy metals at polluted sites in China. J. Environ. Sci. Heal. A 38:823-838.

Wangeline AL, Burkhead JL, Hale KL, Lindblom SD, Terry N, Pilon M, Pilon-Smits EAH (2004) Overexpression of ATP sulfurylase in Indian mustard: Effects on tolerance and accumulation of twelve metals. J. Env. Qual. 33:54-60.

Weber M, Harada E, Vess C, von Roepenack-Lahaye E, Clemens S (2004) Comparative microarray analysis of Arabidopsis thaliana and Arabidopsis halleri roots identifies nicotianamine synthase, a ZIP transporter and other genes as potential metal hyperaccumulation factors. Plant J. 37:269-281.

Wei SH, Zhou QX, Wang X, Cao W, Ren LP, Song YF (2004) Potential of weed species applied to remediation of soils contaminated with heavy metals. J. Environ. Sci. (China) 16:868-873.

Wycisk K, Kim EJ, Schroeder JI, Kramer U (2004) Enhancing the first enzymatic step in the histidine biosynthesis pathway increases the free histidine pool and nickel tolerance in Arabidopsis thaliana. FEBS Lett. 578:128-134.

Xiong YH, Yang XE, Ye ZQ, He ZL (2004) Characteristics of cadmium uptake and accumulation by two contrasting ecotypes of Sedum alfredii Hance. J Environ. Sci. Health A Tox. Hazard Subst. Environ. Eng. 39:2925-2940.

Xue SG, Chen YX, Reeves RD, Baker AJ, Lin Q, Fernando DR (2004) Manganese uptake and accumulation by the hyperaccumulator plant Phytolacca acinosa Roxb. (Phytolaccaceae). Environ. Pollut. 131:393-399.

Zhang YW, Tam NFY, Wong YS (2004) Cloning and characterization of type 2 metallothionein-like gene from a wetland plant, Typha latifolia. Plant Sci. 167:869-877.

Zhao FJ, Dunham SJ, McGrath SP (2002) Arsenic hyperaccumulation by different fern species. New Phytol. $15: 27-31$

Zhao FJ, Lombi E, McGrath SP (2003) Assessing the potential for zinc and cadmium phytoremediation with the hyperaccumulator Thlaspi caerulescens. Plant Soil 249:37-43.

Zhu YL, Pilon-Smits EAH, Jouanin L, Terry N (1999a) Overexpression of glutathione synthetase in Indian mustard enhances cadmium accumulation and tolerance. Plant Physiol. 119:73-79.

Zhu YL, Pilon-Smits EAH, Tarun AS, Weber SU, Jouanin L, Terry N (1999b) Cadmium tolerance and accumulation in indian mustard is enhanced by overexpressing gammaglutamylcysteine synthetase. Plant Physiol. 121:1169-1178. 